\title{
Evaluation of Two Vegetation Indices (NDVI and VCI) Over Asi Basin in Turkey
}

\author{
Mehmet DIKICI ${ }^{1}$ \\ Murat AKSEL ${ }^{2}$
}

\begin{abstract}
Climate change and global warming are among the issues that humanity is most concerned about the future. The growing drought and flood risks that increase despite the taken measures have led to the adoption of an integrated understanding on the topic of water management in recent years. To manage the increased risk of drought and to make sustainable planning, the dimensions of drought should be known first. For this purpose, many drought indices have been developed. The Normalized Difference Vegetation Index (NDVI) and Vegetation Condition Index (VCI), which determined by remote sensing, are two of these. In this study, in which the agricultural drought was analyzed with vegetation indices by taking into consideration the historical drought archive, the Asi Basin was addressed. The data of the Asi Basin, which covers an area of $7800 \mathrm{~km}^{2}$ and was obtained from the Moderate Resolution Imaging Spectroradiometer (MODIS) and Advanced Very High-Resolution Radiometer (AVHRR) satellites, was used in this study. With the satellites benefited in remote sensing and with the Coordination of Information on the Environment (CORINE), where the layers of vegetation were determined, agricultural and forest areas were evaluated separately. The vegetation indices, which change with the increase in temperature, have revealed the necessity of a long-term drought management for the Asi Basin. Result of the work pointed that NDVI index is more appropriated to the Asi Basin than the VCI index to monitor drought.
\end{abstract}

Keywords: Remote sensing, drought index, NDVI, VCI.

\section{INTRODUCTION}

Within the context of the planning, development and management of water resources, which are adversely affected by climate change, the subject of mitigation of expected impacts of drought has gained considerable importance. Management of the increased drought risk and

\footnotetext{
Note:

- This paper has been received on July 10, 2019 and accepted for publication by the Editorial Board on January 7, 2020.

- Discussions on this paper will be accepted by September 30, 2021.

- https://doi.org/10.18400/tekderg.590356

1 Alanya Alaaddin Keykubat University, Department of Civil Engineering, Antalya, Turkey mehmet.dikici@alanya.edu.tr - https://orcid.org/0000-0001-5955-3425

2 Alanya Alaaddin Keykubat University, Department of Civil Engineering, Antalya, Turkey murat.aksel@alanya.edu.tr - https://orcid.org/0000-0002-6456-4396
} 
adaptation to it are only achieved through the development of sustainable and effective drought risk management strategies that adopt holistic approaches. The drought management is part of the disaster management [1]. Drought risk management is the concept and study of prevention and mitigation of the negative consequences of drought hazard and potential disaster through activities and measures aimed at prevention, harm reduction and preparedness [2]. Drought risk management is an important part of water resources management policies and strategies. National drought policies play a major role in managing drought risk [3]. In order to reduce the impacts caused by drought, drought management plans need to be prepared based on country legislation and taking into account the specific drought characteristics and impacts of the basin [4]. It is very important that these plans should be prepared as part of the basin management plan in order to create integrity. In addition, the involvement of all stakeholders, affected sectors, decision makers and experts in the process of creating plans contributes greatly to the success of drought management plans. Elements of drought management plan include knowledge of the characteristics of the river basin, investigation of historical drought incidents in the basin, evaluation of the risk that may occur, determination of indicators and threshold values for drought analysis, establishment of a precautionary program to reduce the effects of drought, instillation of early warning system and establishment of the organizational structure [5]. Drought risk management covers the early warning system including hazard, exposure, impact assessment and vulnerability, drought monitoring and forecasting; it also covers the stages of preparation and harm reduction [1]. Early warning systems, one of the most important elements of drought management plans, are used within the framework of two targets, drought monitoring and drought forecasting. Drought early warning systems typically aim to monitor, assess and present information about climate, hydrological properties, water supply conditions and trends. The objective here is to take action within a drought risk management plan to reduce potential impacts and to provide early information before or during the onset of drought. Since drought is a hydrological phenomenon that begins slowly and progresses monitoring and analysis of drought are of great importance [6]. Monitoring and analysis of drought is done through various indicators and indices. These indicators and indices enable the characterization of drought by providing information about the severity, location, duration and timing of drought in order to determine, classify, and monitor drought conditions. Some indicators and indices can also be used to validate drought indicators that are modeled, remotely detected or assimilated to the model of remote sensing data [6].

Thanks to the geographic information systems and the power of developing computing and imaging systems, it has been possible to overlap, map and compare different indicators and indices [6]. Location of the Asi Basin is shown in Figure 1. Drought analysis study for the Asi Basin, which is addressed in this study, has been investigated by various researchers for different indices. The Asi Basin is one of Turkey's 25 basins and covers all and/or part of Hatay, Kilis, Gaziantep, Adana and Osmaniye provinces.

Studies focusing on the Asi Basin are usually related to the recent past, however, there are some studies by historians and researchers that evaluate the records of a few centuries ago. It is known that in the Ottoman Empire in the $16^{\text {th }}$ century and later (the period of 1564,1565 $67,1586,1588$ and 1560), some drought and famine events occurred. Also in the following periods, droughts lasting two years were experienced (seven times in the Mediterranean region, five times in the Black Sea region). The years of drought in both regions were 1676, $1679,1696,1715,1725,1746,1757,1797,1815,1887$ [7]. Two great disasters processed in 


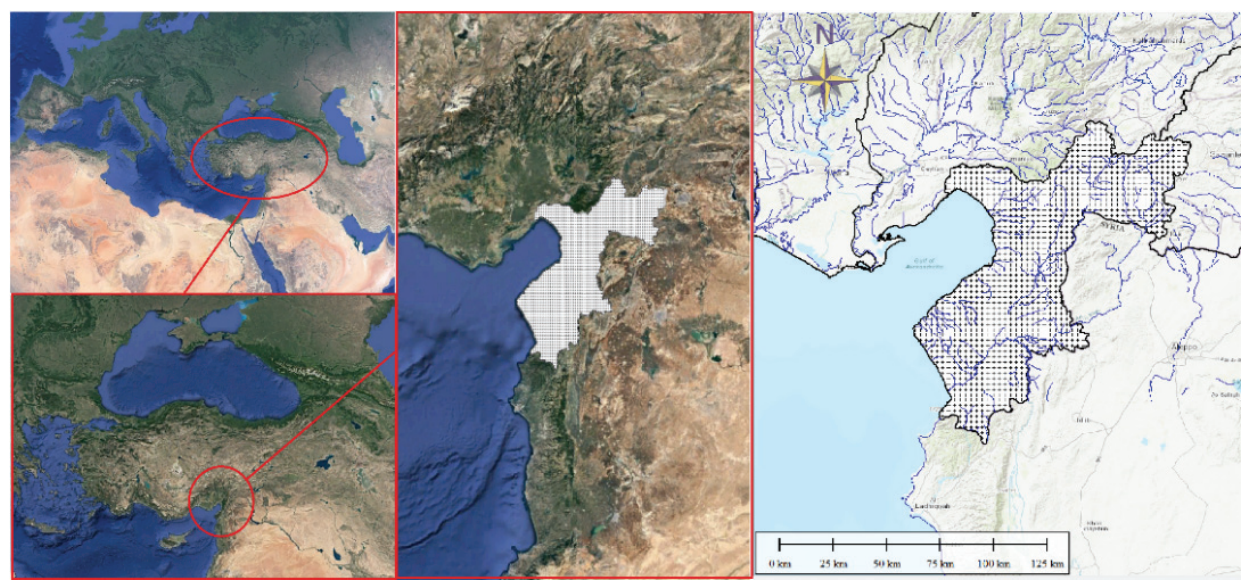

Figure 1 - Asi Basin

the Ottoman Empire in $19^{\text {th }}$ century were identified by Sariköse [8]. The first was the famine caused by a severe drought in 1845, and the other was the famine experienced in 1874-1875. In the study, it was stated that the drought was effective throughout the Ottoman geography in the $19^{\text {th }}$ century. In the study carried out by Akbas, arid years affecting the basin were determined by the analysis conducted based on the study called "Significant drought years in Turkey", and by focusing on Turkey according to Palmer drought severity index [9]. As a result of that study, it was determined that drought conditions were observed in 1972-1974, 1989, 1991, 2001, and 2007 - 2008 periods in the Asi Basin. According to the study carried out by Simsek et al. [10], it was observed that the drought conditions prevailed throughout all the basin during the 2013-2014 years, especially during the summer months when the drought was experienced throughout Turkey and throughout the agricultural year. According to the hydrological drought analysis results conducted by using the Streamflow Drought Index (SDI) [11] method to identify the total annual natural stream flows of the Asi Basin between 1981 and 2010, "moderate drought" was observed in 1991, 2001 and 2007-2008 periods [12]. In the study conducted by Gumus, hydrological drought analysis was performed by using 52-year flow data (1954-2005) obtained from four streamflow observation stations $(1905,1906,1907,1908)$ in Asi Basin [13]. SDI method was used to determine the drought. Using monthly flow data, the intensity, size and distribution of the dry and humid periods of the Asi Basin were determined by 3,6 and 12 month SDI values. As a result of the study, based on the average SDI values of all time scales, it was observed that the number of year lasting dry between 1980 and 2005 was much higher than the number of year lasting dry between 1954 and 1979. In addition, excessive dry years on the basis of the basin were determined as 2000 and 2001. According to the SDI-12 values calculated to monitor the annual drought and humidity, it was observed that the rate of drought occurrence in all stations, except Station 1907, was more than the rate of humidity occurrence. The rate of being Excessive Dry (ED) of all stations was around 3\%, Severe Dry (SD) was around 5\%, and Moderate Dry (MD) was around 10\%. It was determined that the highest drought calculated by SDI-12 was at the stations 1905,1907 and 1908 with $34.6 \%$, and the highest humidity was at the station 1907 with $38.0 \%$. When all values are examined together, it is 
seen that the dry and humid periods are close to each other. The occurrence percentage of dry/humid periods are given in Figure 2.

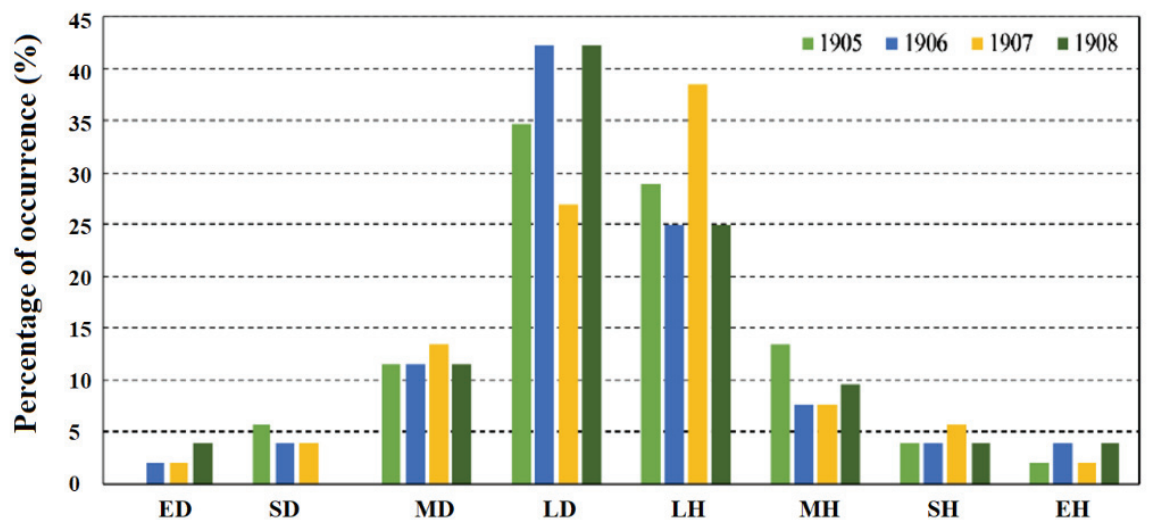

Figure 2 - Rates of being dry/humid of the stations

NDVI and VCI indices have been widely used in monitoring of vegetation for the analysis of agricultural productivity by remote sensing methods. [14]. In this study, the application of NDVI and VCI indices, which have gained importance in recent years, to the Asi Basin by using remote sensing method is emphasized.

\section{MATERIALS AND METHOD}

\subsection{Remotely Sensed Data}

By the development of space technology, Remote Sensing (RS) applications have rapidly increased as integrated with powerful software-hardware opportunities and Geographic Information Systems (GIS). The ability to easily transfer spatial data from space via satellite and various ground data to GIS environment has increased the possibilities of analysis on natural resource management, land cover and land use, environmental and ecological analysis, disaster and risk assessment, meteorological, hydrological and agricultural applications, etc. Remote sensing data is used effectively and intensively in various hydrological applications. Drought studies are among these practices. The vegetation and soil moisture that can be obtained by remote sensing are the data sources commonly used in drought studies. High resolution vegetation change information provided by vegetation indices (such as NDVI) temporally and spatially can contribute to drought information. Vegetation indices are preferred because they are both easy to use and do not require any assumptions and/or additional information except for themselves [15]. Plant indices are parameters which can be determined by remote sensing methods and which have very wide application area. The reason for this is that the green vegetation gives high reflection values in the near-infrared region of the electromagnetic spectrum [16]. Certain pigments in plant leaves absorb strongly the rays on the visible wavelengths (390 nm-700 nm wavelength range). From these rays, especially red (620 nm- $750 \mathrm{~nm}$ wavelength range) wavelength rays 
are absorbed by the plant to use during photosynthesis. On the other hand, it strongly reflects the near-infrared rays (760 nm- $900 \mathrm{~nm}$ wavelength range) that are invisible to the human eye. Vegetation indices use this information to make inference about the greenery of the plant. The vegetation spectrum is given in Figure 3 [17]. Changing reflection properties of vegetation in its maturation period from the early spring period to the late maturity season and harvest time causes plant indices to change. Most of the satellite sensors measure red and close infrared light waves reflected from the earth. By using mathematical formulas, raw satellite data on these light waves are converted into vegetation indices. Vegetation indices are indicators that define the greenness of the plant (that is, its relative density) and health status for each cell in the satellite image. Not all of the vegetation indices obtain the greenness of the vegetation by directly measuring visible and near-infrared wavelengths; some indirectly perceive the change in the vegetation. For example, some vegetation indices can obtain information about plant changes on the surface by using temperature change information on the earth surface. In other words, the water content in the plant enables the plant to release less heat in the day compared to the soil, and the information on the vegetation change is obtained by using the information about the temperature change during the day. These indices have the potential to provide important information about the drought experienced in the basin because they are sensitive to vegetation. For this purpose, there are various indices that are widely used in the literature such as Enhanced Vegetation Index (EVI), Evaporative Stress Index (ESI), Normalized Difference Vegetation Index (NDVI), Temperature Condition Index (TCI), Vegetation Condition Index (VCI), Vegetation Drought Response Index (VegDRI), Vegetation Health Index (VHI), Water Requirement Satisfaction Index (WRSI), Normalized Difference Water Index (NDWI), Land Surface Water Index (LSWI) and Soil Adjusted Vegetation Index (SAVI).

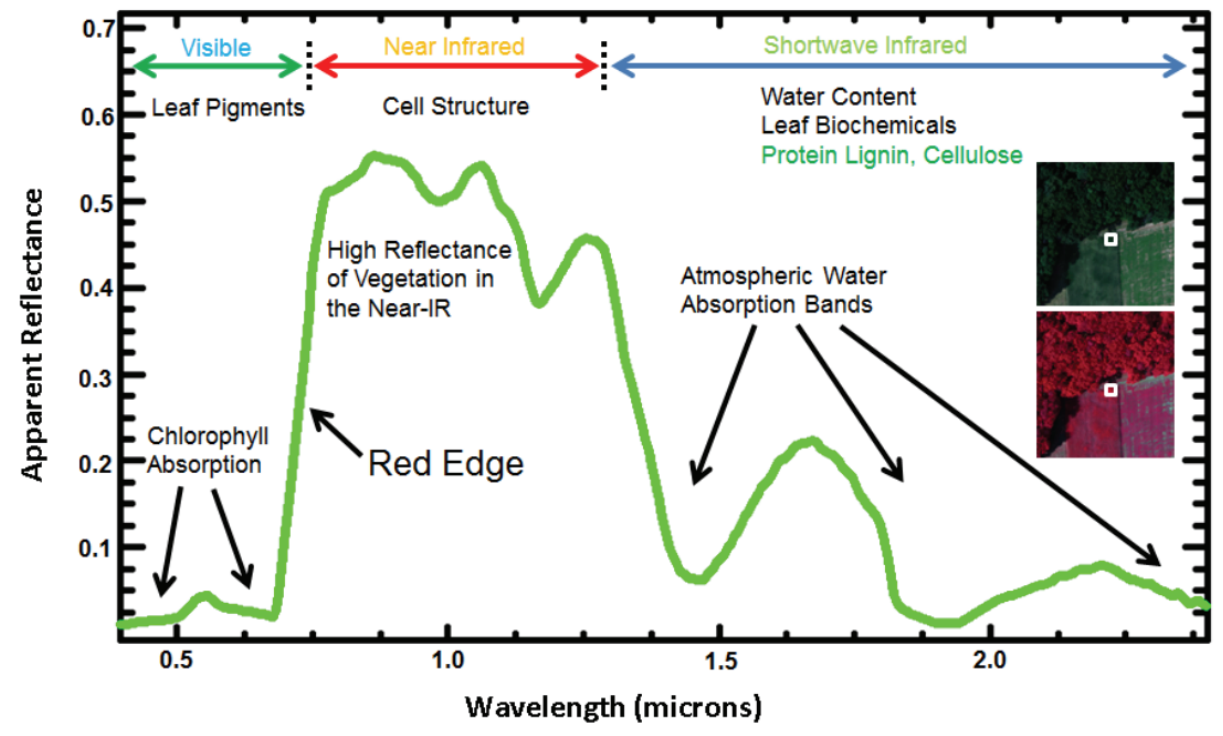

Figure 3 - Vegetation spectrum [17] 
Within the scope of the Asi Basin drought analysis study, the use of vegetation indices which provide information about the change in plant green were preferred. In this direction, NDVI and VCI were analyzed as temporal and spatial within the Asi Basin boundaries.

\subsection{Normalized Difference Vegetation Index (NDVI)}

Normalized Difference Vegetation Index (NDVI) is one of the most widely used tools for monitoring green vegetation by using remote sensing data. NDVI is also one of the most widely used vegetation indices in forest classification and agricultural studies as well as the identification of the change in land cover. Certain pigments in plant leaves absorb strongly the rays in visible wavelengths (390 nm - $700 \mathrm{~nm}$ wavelength), especially the rays in red wavelengths $(620 \mathrm{~nm}-700 \mathrm{~nm}$ wavelength), in order to use during photosynthesis. On the other hand, rays that are in the near-infrared wavelengths $(760 \mathrm{~nm}-900 \mathrm{~nm}$ wavelength) and invisible to human eye are strongly reflected through spongy mesophyll in the plant. NDVI makes inference about the greenery of the plant by normalizing this difference information. Different ranges of red and near-infrared wavelengths are measured using sensors by different satellites. Based on observations of satellite images on near-infrared (NIR) and red (RED) wavelengths, NDVI is calculated as in Equation 1.

$$
N D V I=\frac{(N I R-R E D)}{(N I R+R E D)}
$$

Theoretically, NDVI values range from $(-1)$ to $(+1)$, and more rays are reflected in the nearinfrared wavelengths compared to the red wavelength. In areas where green vegetation is more, the index value approaches to $(+1)$ (NIR-RED difference increases and approaches to NIR + RED). Clouds, water and snow cover have low NDVI index values (-). Bare soil and weak vegetation shows near-zero or (-) NDVI value. On an NDVI map showing areas where agriculture is intensive, areas with low NDVI values point to weak plant development due to a variety of reasons such as drought, extreme humidity, disease and pests. On the other hand, high NDVI values show the healthy areas of plant development [18]. For example, in areas consisting of barren rock, sand, or generally snowy areas, NDVI values are 0.1 or smaller. In shrubs and grazing areas, or in areas covered with sparse vegetation such as crops at the harvest period, NDVI values are observed in the range of $0.2-0.5$. The highest NDVI values range from about $0.6-0.9$ in temperate and tropical forests or in the maximum growth stage of crops. NDVI is considered as the main indicator of the biomass amount of plants and the index value of leaf area and is used for monitoring plant growth and estimating the yield during the growth period. NDVI is particularly useful for monitoring plant status on a global scale because the normalization phase used during its calculation can compensate some factors such as varying brightness conditions, surface slope and angle of view. The average of NDVI values can be taken in order to determine the normal growth conditions for a given year in a region. In this way, the health of the plant can be assessed by characterizing according to normal. When the NDVI values are analyzed as temporal, it can give information about the plant's development, whether it is under water stress, and the changes that occur as a result of human activities such as deforestation or fire. NDVI data of NOAA, AVHRR and MODIS satellites are widely used satellite images to monitor vegetation changes in large areas. MODIS data was used to detect drought from vegetation in the Seyhan Basin[19]. AVHRR and MODIS satellites provide NDVI data as ready for use; therefor, no 
atmospheric correction is required in these satellite data, and thus, no additional data is needed for Atmospheric correction. The data on NIR and RED wavelengths obtained from Landsat satellite need atmospheric correction before the NDVI is calculated. Although the normalization phase reduces the effect of these atmospheric components on the NDVI, the study used the NDVI data obtained from AVRR and MODIS satellites that did not require atmospheric correction. The time interval, resolution and repeat time of the NDVI values obtained from these two satellites are given in Table 1.

Table 1 - Data Properties of AVHRR and MODIS Satellites

\begin{tabular}{|l|c|c|c|c|}
\hline Satellite & Data Name & Time Interval & Resolution & $\begin{array}{c}\text { Repetition } \\
\text { Period }\end{array}$ \\
\hline $\begin{array}{l}\text { AVHRR-The Advanced } \\
\text { Very High Resolution } \\
\text { Radiometer }\end{array}$ & AVHRR NDVI & $1981-2016$ & $3.6 \mathrm{~km}$ & 16 days \\
\hline $\begin{array}{l}\text { AVHRR-The Advanced } \\
\text { Very High Resolution } \\
\text { Radiometer }\end{array}$ & $\begin{array}{c}\text { AVHRR } \\
\text { NDVI3gc }\end{array}$ & $1981-2015$ & $8.0 \mathrm{~km}$ & 16 days \\
\hline $\begin{array}{l}\text { MODIS-The Moderate } \\
\text { Resolution Imaging } \\
\text { Spectroradiometer }\end{array}$ & $\begin{array}{c}\text { MODIS } \\
\text { MOD13Q1 } \\
\text { NDVI }\end{array}$ & $2000-2016$ & $250 \mathrm{~m}$ & 16 days \\
\hline
\end{tabular}

\subsection{Advanced Very High Resolution Radiometer (AVHRR)}

The Advanced Very High Resolution Radiometer (AVHRR) first began its observations on the TYROS-N that was sent to space in 1978 and then on the NOAA satellite. The basic properties of AVHRR have not changed and AVHRR has been continuously utilized in Earth Observation. AVHRR provides approximately $3.6 \mathrm{~km}$ of spatial resolution and the band area is 2,399 $\mathrm{km}$ wide. Whereas NOAA gets around the world 14 times a day, AVHRR observes the same area twice a day. Wide-band images measured by AVHRR are suitable for a variety of purposes, such as cloud cover area, vegetation index and surface temperature.

There are several studies in the literature which show that the NDVI values calculated by using AVHRR satellite data are different from the NDVI values obtained from other satellite data [20-26] The main reasons for the fact that AVHRR NDVI values are problematic are inadequate atmospheric correction, orbital drift and bidirectional reflectance distribution function, correction deficiencies, and scanning and solar angle effects $[25,26]$ The AVHRR NDVI3G product was obtained as a result of the study conducted to partially correct the time series of AVHRR NDVI [26]. In addition to the AVHRR NDVI product, the time series of AVHRR NDVI3g products were also used in the scope of this study.

\subsection{MODIS}

The National Aeronautics and Space Administration (NASA) blasted off the MODIS sensor on the Terra platform on December 18, 1999 and on the Aqua platform on May 4, 2002 to 
space within the framework of the Earth Observing System (EOS) program [27]. The MODIS sensor on Terra and Aqua satellites is used to obtain comprehensive data on ground, ocean and atmospheric processes. The design of MODIS goes back to previous sensors (such as the AVHRR sensor used in NOAA satellite). However, the difference of it from the previous sensors is that both the temporal and positional resolution of it is high, and it can collect data from 36 separate spectral bands from $0.4 \mu \mathrm{m}$ to $14 \mu \mathrm{m}$ [28]. The MODIS sensor has a positional resolution of $250 \mathrm{~m}$ between 1-2 bands, $500 \mathrm{~m}$ between 3-7 bands and $1 \mathrm{~km}$ between $8-36$ bands [29]. MODIS observations, used in the ocean and atmosphere studies in the first place, today provide important facilities in vegetation, land use, and drought and Agriculture studies. Although MODIS images are taken twice a day, NDVI products are published in 8-day composites [30]. MODIS NDVI images consisting of 4800 rows and 4800 columns allow analyzing the changes in vegetation activity in a wide range of areas $[31,32]$. In many studies, the NDVI data obtained from different satellites have been compared. While some studies argue that MODIS NDVI values are better than AVHRR NDVI and AVHRR NDVI3g product [33], some studies indicate that long-term trends show high consistency with each other [34]. In this study, AVHRR NDVI, AVHRR NDVI3g and MODIS NDVI values were used and NDVI time series were compared among themselves. The comparative graph is presented in Figure 4.

In drought studies, since the definitions of the drought period are generally made as deviations from the normal values obtained for long periods, the mean seasonality of NDVI values and the anomaly values obtained by subtracting these seasonal data from the original data were compared. When calculating the anomaly time series of the data series, the period of 2001-2015 when all three data were observed was selected. When the anomaly and seasonal values are compared, it is observed that the actual change between the data is due to the seasonal time series and the difference among the anomaly values is less on the average. This shows that the differences between NDVI datasets can be minimized by calculating as an anomaly in drought studies. Normal, seasonal and anomaly NDVI data charts are given in Figure 5 As a result of the large turbulence and evaluation of the spatial distribution in AVHRR data, the data set was found to contain too much error. Therefore, in the study, the AVHRR NDVI-3G version whose quality control was done was used in conjunction with MODIS NDVI in the calculations carried out with drought indices.

MODIS-VCl

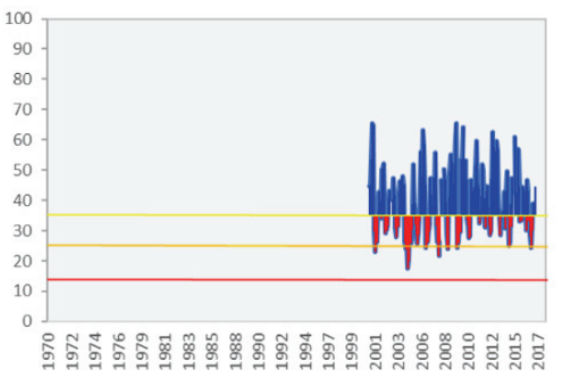

AVHRR-VCl

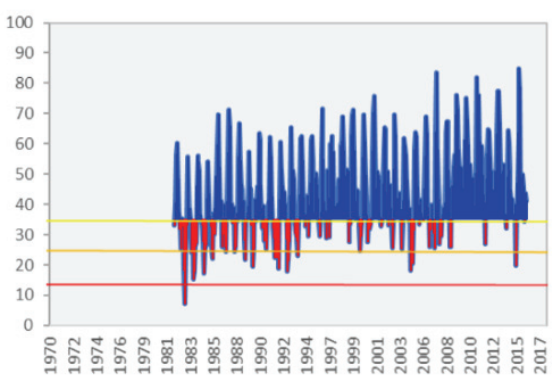

Moderate drought
二- Serere droght
E Etreme drought

Figure 4 - Time series of the field average of MODIS (2001-2016) and AVHRR (19822015) VCI values for Asi Basin 

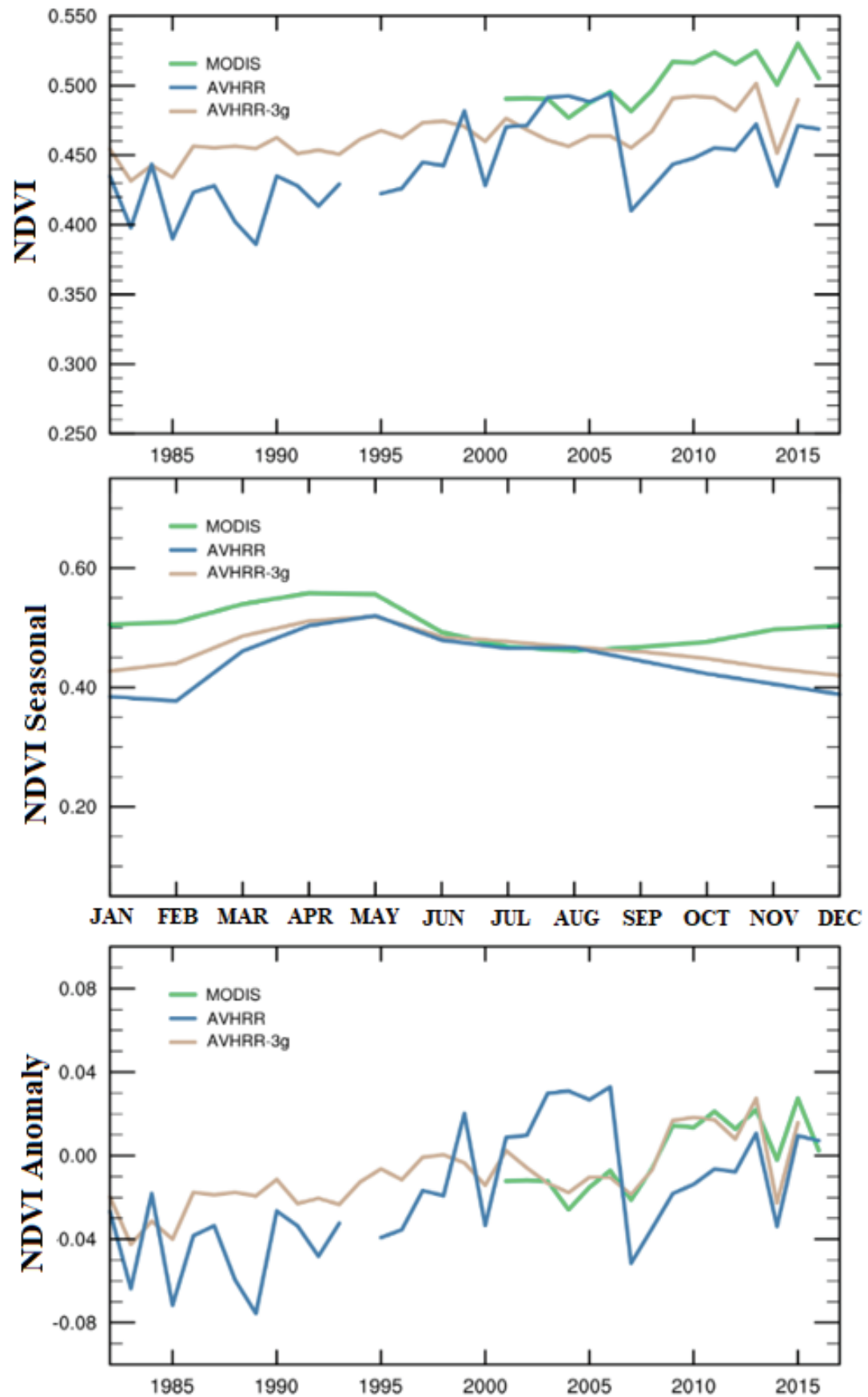

Figure 5 - NDVI time series obtained from different satellites for the Asi Basin 


\subsection{Vegetation Condition Index (VCI)}

VCI can provide information about the start, duration and severity of drought by taking into account the effect of drought on vegetation. Together with NDVI, it is used for the evaluation of vegetation in drought conditions affecting agriculture [35]. VCI compares the NDVI data for a given period with the highest and lowest values of the NDVI data for the whole period [36]. VCI is expressed as a percentage (\%) and provides information about when the highest and lowest values of the observed value occurred in previous years. While the low VCI values indicate that the vegetation is in bad condition, the high VCI values indicate that the vegetation was in good condition [37]. Considering that the data derived from satellite data are obtained from many cells in the spatial sense, the $V C I_{i}$ for any cell $(i)$ is calculated as in Equation 2.

$V C I_{i}=\frac{\left(N D V I_{i}-N D V I_{\min }\right)}{\left(N D V I_{\max }-N D V I_{\min }\right)} \times 100$

VCI can be considered as the normalized state of NDVI. In this study, in addition to NDVI, the VCI index was also evaluated because VCI is a more appropriate index for assessing the amount of deviation of vegetation from normal condition. Therefore, VCI allows an opportunity for comparison of the simultaneously measured NDVI values for different ecosystems (that is for different vegetation in different geographies). Since VCI can distinguish short-term climate signal from long-term ecological signal, it is a better indicator of soil moisture deficit than NDVI. The importance of VCI is related to the vitality of the vegetation examined by the vegetation index [38]. VCI data, like NDVI, has high resolution and good field coverage. There are various studies in literature on the use of VCI for drought analysis $[35,39,40]$.

\section{RESULTS AND DISCUSSION}

\subsection{Drought Intensity Analysis for Vegetation Condition Index}

For this study, the Vegetation Condition Index (VCI) was calculated to compare the drought determined as a result of the drought analysis for the Asi Basin by using the NDVI values obtained from MODIS and AVHRR satellite data. In this direction, for each $250 \mathrm{~m}$ satellite cell within the basin area, the VCI time series obtained using satellite data for the years 20012016 are presented in Figure 4. While VCI values shown in red in time series indicate drought in plant condition, the values shown by blue can be interpreted as the plant condition in the seasonal and climatic conditions.

The graphic in which the comparison of MODIS VCI and AVHRR-3G VCI of the Asi Basin is shown is given in Figure 6. It is seen that the index values are frequently overlapping but calculated magnitudes are different. Root mean square error between two data was calculated as 20. The main reason is MODIS spatial resolution is higher than the AVHRR and MODIS data are more accurate than the AVHRR for VCI[41]. 


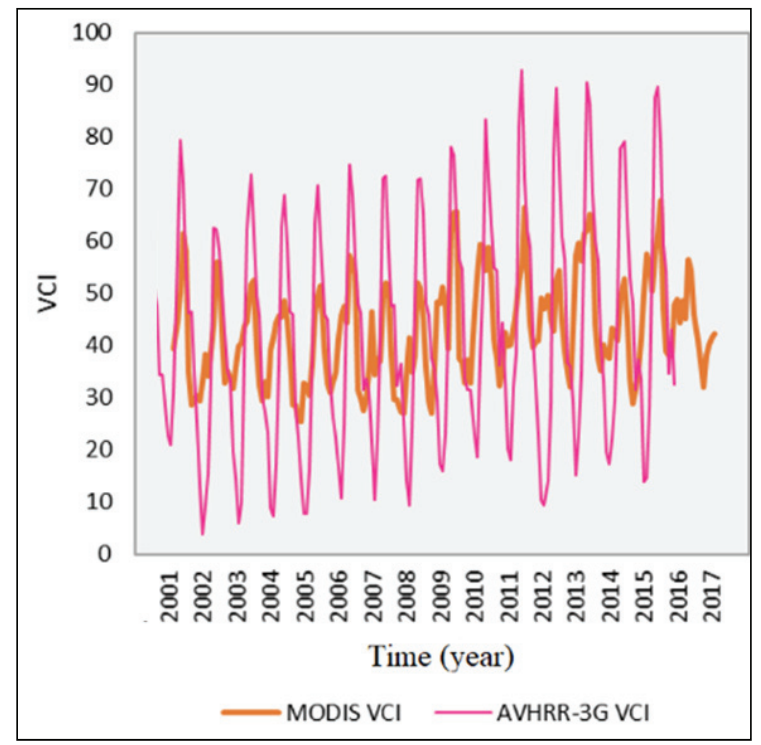

Figure 6 - Comparison of MODIS VCI and AVHRR-3G VCI of the Asi Basin

\subsection{Agricultural Drought Analysis}

Within the scope of drought index studies, climate change responses of the unregularly irrigated or non-irrigated agricultural fields and vegetation areas in Asi Basin should be analyzed. The CORINE (Coordination of Information on the Environment) layers to be used for these analyses were determined and the changes of the NDVI time series were calculated on these layers. While selecting classes, the areas where vegetation was not subjected to human interventions such as irrigation, fertilization and changes were mostly due to natural processes were targeted. The distribution of these determined CORINE layers on the basin is given in Figure 7.

The fact that the AVHRR-3G and MODIS NDVI data used in the analysis were at different resolutions led to the differentiation of the classified areas. Reason of this was that the majority value (that is, dominant class) was used when the category-based high-resolution data was moved to a coarser resolution. The 8-km resolution pixel in AVHRR-3G data corresponds to 250-m resolution 1024 pixels in MODIS data. Therefore, some pixels consist of the mosaic of classes of very different properties, as well as the class that is designated as the dominant class. Another problem caused by the resolution difference is that some classes in the minority, which can be detected at high resolution, cannot be expressed at a coarse resolution and disappear. This can be seen in the graphs below. Some classes that can be detected in MODIS data cannot be expressed in AVHRR-3G resolution: The fact that the determined classes can be found in geographically discrete areas in both data can sometimes lead to the layers take very discrete values. Another issue to be considered during the evaluation is that land use may change over time. This change is inevitable, especially given a long period of time, such as 1982-2016. With the increase in population, it should be taken into consideration that forest areas can become agricultural areas and agricultural areas can 
become artificial lands and that the opposite situation may sometimes arise due to the reasons such as migration from the village to the city and this may result in artificial tendencies.

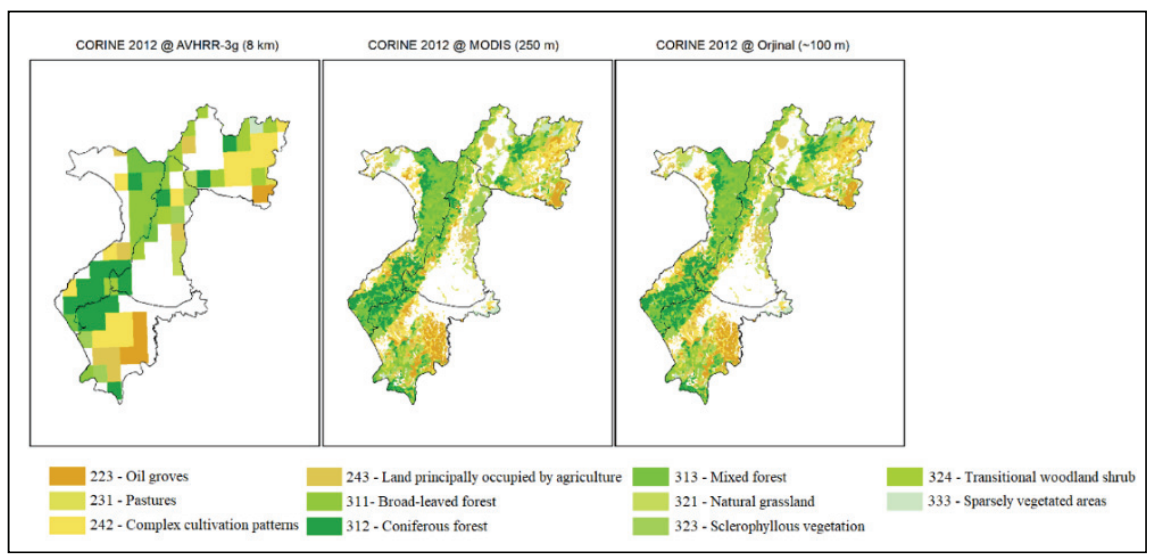

Figure 7 - The layers examined for the CORINE NDVI comparison in the Asi Basin

In CORINE 2012 land use data, the NDVI temporal variation series for agricultural areas starting with code 2 are given as annual and seasonal in Figure 8. AOS (December-JanuaryFebruary) refers to winter months, MNM (March-April-May) spring months, HTA (JuneJuly-August) summer months, and EEK (September-October-November) autumn months.

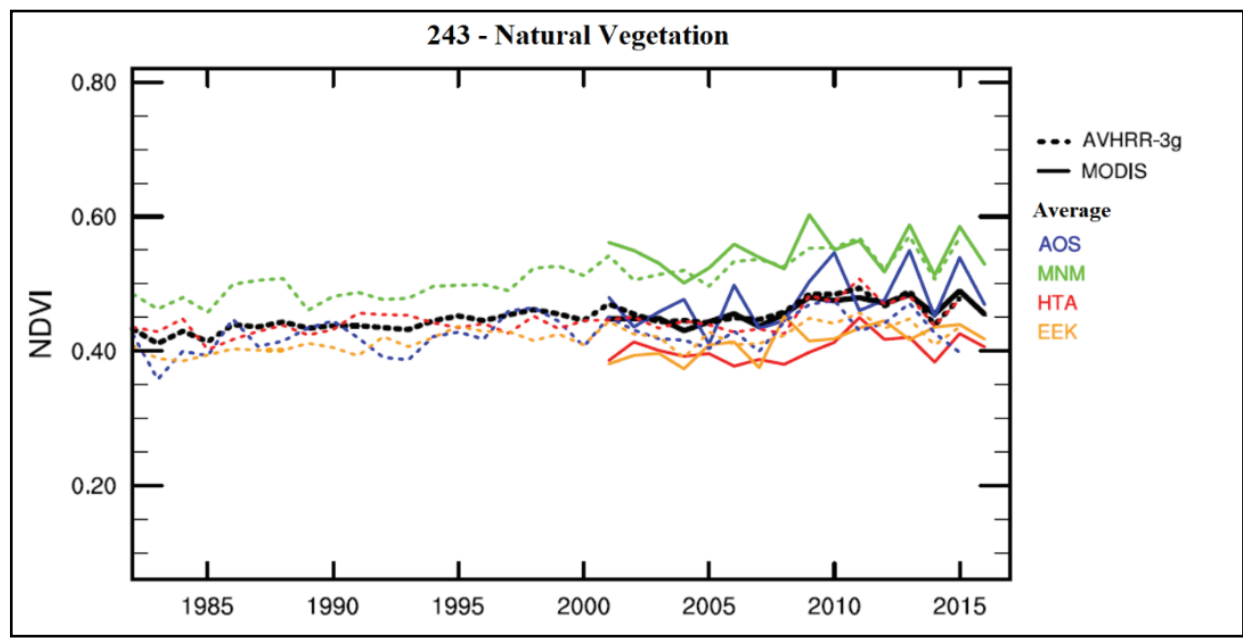

Figure 8 - ASI Basin CORINE 243 - Natural vegetation NDVI temporal change

When the examined time series of the layers is evaluated in general, it is observed that NDVI values were relatively low in 2002 and 2004 and were significantly increased between 2007 and 2013. Except the fluctuations in the data, it was observed that NDVI values were higher 
in the spring months and lower in the summer months. Because the pasture class had too small areas to be represented at the AVHRR-3G resolution, it was not included in the figure instead of graphics. In the olive groves, which are resistant to cold, do not shed leaves, and are also known as the everlasting tree, values above average were observed in winter months, unlike other classes. It was considered that the olive groves was not well represented in indices. Since the class of natural vegetation was in large areas, it was well represented in both data and it was observed that it received close values to each other. This layer, where human influence is limited, is one of the classes where the effects of drought on plants can be better observed and it showed significant decreases in 1982, 1989, 2004, 2007, 2014. The highest values were observed in 2011 and 2015. The series of annual and seasonal temporal changes of NDVI that belongs to sparse plant areas and that start with code 3 of CORINE classification is presented in Figure 9.

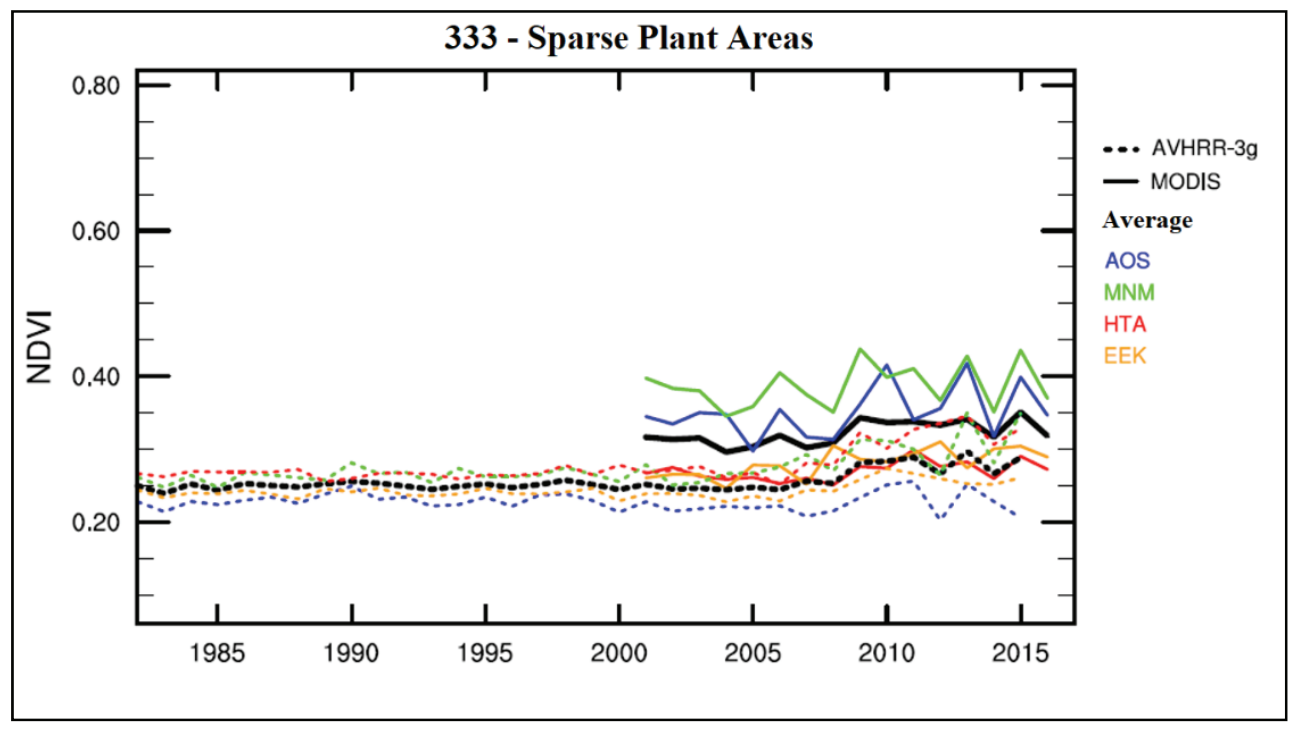

Figure 9 - Asi Basin CORINE 333 -NDVI Time series of sparse plant areas

The difference between the calculated NDVI of two data increases due to dilution in vegetation.

\section{CONCLUSION}

This study set out to assess NDVI and VCI vegetation indices over Asi Basin by using MODIS and AVHRR-3G data. In the examined forest layers, annual changes in agricultural areas was seen in a similar way and in NDVI calculations, while the lowest values were determined in winter and the highest values were determined in summer and spring. Whereas the cold-resistant and non-deciduous needle-leaved trees (conifers) got the highest values in MODIS data during the winter months, they got the lowest values in AVHRR-3G data. Therefore, it was assessed that as a result of the lack of vegetation class separation at $8 \mathrm{~km}$ resolution, the needle-leaved forests were mixed with other classes. It was also evaluated that 
because the deciduous (non-evergreen) trees were in the same pixels with the needle-leaved trees, they got much lower values in winter than expected. In general, since 2000, there has been an increase in NDVI values. This may be a result of the decrease in the snow cover, which reduces NDVI values due to the result of climate change, in terms of process and area. It is thought that the positive contribution of increasing temperature values to the photosynthesis process may have consequences on NDVI values. Changes in land use may also cause differences in NDVI values. For the Asi Basin, the periods when indices and historical data jointly point to drought were identified as 1973-1974, 1989-1991, 1993-1994, 2000-2001, 2004-2005, 2014 and 2016. For the Asi Basin, a process in which droughts management becomes more and more important. Precipitation based hydrological drought analysis which is mentioned in Figure 2 shows parallelism with vegetation based drought indices results.

Basin based water resources planning studies have an important place in civil engineering. Current and future status of the watershed are always examined in investment planning, water resources management, structural and administrative solutions. In terms of water resources and irrigation planning, this study is important for the Asi Basin. As can be seen from the NDVI and VCI indices, it is beneficial to develop water resources and take additional precautions due to climate change and population growth for the Asi Basin. In addition, this study showed that the NDVI index is better appropriated to the Asi Basin than the VCI index.

\section{Acknowledgement}

We would like to thank General Directorate of Water Management of The Ministry of Forest and Water Management for their contribution to providing the data in this study.

\section{References}

[1] D.A. Wilhite, Drought: A Global Assessment, 2000. doi:10.4324/9781315830896.

[2] UNDP, DROUGHT RISK MANAGEMENT, 2016.

[3] D.A. Wilhite, M.V.K. Sivakumar, R. Pulwarty, Managing drought risk in a changing climate: The role of national drought policy, Weather Clim. Extrem. 3 (2014) 4-13. doi:10.1016/j.wace.2014.01.002.

[4] Water Scarcity and Droughts Expert Network, Drought Management Plan Report Including Agricultural, Drought Indicators and Climate Change Aspects European Commission Directorate of Environment, 2008.

[5] G.W.P.C. and E. Europe, Guidelines for preparation of the Drought Management Plans Guidelines for preparation of the Drought Management Plans, 2015.

[6] M.D. Svoboda, B.A. Fuchs, Handbook of drought indicators and indices, 2017. doi:10.1201/b22009.

[7] S. Tekin, 19.Yüzyılın Sonu 20.Yüzyılın Başlarında Batı Anadolu'da Yaşanan Kuraklık Olayları, He J. Acad. Soc. Sci. Stud. Int. (2015) 329-341.

[8] S.T. Sarıköse, XIX. Yüzyilda Çukurova'da Doğal Afetler Ve Salgin Hastaliklar, 2013. 
[9] A. Akbaş, Türkiye Üzerindeki Önemli Kurak Yıllar, Coğrafi Bilim. Derg. 12 (2014) 101-118. doi:10.1501/Cogbil_0000000155.

[10] O. Şimşek, M. Yildirim, N. Gördebil, 2013 - 2014 Tarim Yili Kurakli Analizi, (2014).

[11] I. Nalbantis, Evaluation of a Hydrological Drought Index, Eur. Water. 2324 (2008) 6777.

[12] A.D. Özdemir, M.K. Erkuş, Havza Bazında Hidrolojik Kuraklık Analizi, in: IX Natl. Hydrol. Congr., 2017.

[13] V. Gümüş, Akım Kuraklık İndeksi ile Asi Havzasının Hidrolojik Kuraklık Analizi, 5 (2017) 65-73.

[14] F.B. Sanli, A. Delen, Assessment of vegetation indices for the determination of agricultural crop types, J. Environ. Prot. Ecol. 19 (2018) 417-425.

[15] B. Bulut, M.T. Yılmaz, Türkiye'deki 2007 ve 2013 Yılı Kuraklıklarının NOAH Hidrolojik Modeli ile İncelenmesi, Teknik Dergi. 27 (2016) 7619-7634. http://dergipark.gov.tr/tekderg/issue/28142/299116.

[16] O. Gökdemir, A. Arikan, NOAA-AVHRR Uydu Girintileri ile Bölgesel BuharlaşmaTerlemenin Belirlenmesi, (1999) 187-198.

[17] M.R. Elowitz, What is Imaging Spectroscopy (Hyperspectral Imaging), (2018). http://www.markelowitz.com/Hyperspectral.html (accessed May 28, 2019).

[18] H. Yıldız, A. Mermer, E. Ünal, F. Akbaş, Türkiye Bitki Örtüsünün NDVI Verileri ile Zamansal ve Mekansal Analizi, Tarla Bitk. Merk. Araştırma Enstitüsü Derg. 21 (2012) 50-56. doi:10.21566/tbmaed.43176.

[19] M.A. ÇELIK, Investigation the Effect of the Drought Year of 2014 on the Vegetation in the Seyhan Basin, J. Int. Soc. Res. 10 (2017) 424-432. doi:10.17719/jisr.20175434606.

[20] A.P.. Cracknel, Advanced very high resolution radiometer, CRC Press, 1997.

[21] C.J. Tucker, J.E. Pinzon, M.E. Brown, D.A. Slayback, E.W. Pak, R. Mahoney, E.F. Vermote, N. El Saleous, An extended AVHRR 8-km NDVI dataset compatible with MODIS and SPOT vegetation NDVI data, Int. J. Remote Sens. 26 (2005) 4485-4498. doi:10.1080/01431160500168686.

[22] J.E. Pinzón, M.E. Brown, C.J. Tucker, EMD Correction of Orbital Drift Artifacts in Satellite Data Stream, in: Hilbert?Huang Transform Its Appl., WORLD SCIENTIFIC, 2013: pp. 241-260. doi:10.1142/9789814508247_0011.

[23] H. Yin, T. Udelhoven, R. Fensholt, D. Pflugmacher, P. Hostert, How normalized difference vegetation index (NDVI) trends from advanced very high resolution radiometer (AVHRR) and système probatoire d'observation de la terre vegetation (SPOT VGT) time series differ in agricultural areas: An inner mongolian case study, Remote Sens. 4 (2012) 3364-3389. doi:10.5829/idosi.mejsr.2012.12.3.64113.

[24] E. Lee, Analysis of MODIS 250 m NDVI Using Different Time-Series Data for Crop Type Separability, 2014. 
[25] J.R. Nagol, E.F. Vermote, S.D. Prince, Quantification of impact of orbital drift on interannual trends in AVHRR NDVI data, Remote Sens. 6 (2014) 6680-6687. doi:10.3390/rs6076680.

[26] J.E. Pinzon, C.J. Tucker, A non-stationary 1981-2012 AVHRR NDVI3g time series, Remote Sens. 6 (2014) 6929-6960. doi:10.3390/rs6086929.

[27] D.K. Hall, G.A. Riggs, N.E. Digirolamo, K.J. Bayr, MODIS Snow-Cover Products, Remote Sens. Environ. 83 (2002) 181-194. doi:10.1016/S0034-4257(02)00095-0.

[28] J.W. Pomeroy, D.M. Gray, T. Brown, N.R. Hedstrom, W.L. Quinton, R.J. Granger, S.K. Carey, The cold regions hydrological model: a platform for basing process representation and model structure on physical evidence, Hydrol. Process. 21 (2007) 1534-1547. doi:10.1002/hyp.6787.

[29] T. Lillesand, R.W. Kiefer, J. Chipman, Remote Sensing and Image Interpretation, 7th ed., Wiley, 2015.

[30] NASA, NDVI Nasa Data, (n.d.). https://gimms.gsfc.nasa.gov/MODIS/std/GMOD09Q1/tif/NDVI/ (accessed April 25, 2019).

[31] M.A. Celik, M. Karabulut, Ahir Daği (Kahramanmaraş) ve Çevresinde Bitki Örtüsü ile Yağiş Koşullari Arasindaki İlişkilerin MODIS Verileri Kullanilarak İncelenmesi, Havacılık VE Uzay Teknol. Derg. 6 (2013) 123-133.

[32] S. Aksoy, O. Gorucu, E. Sertel, Drought monitoring using MODIS derived indices and google earth engine platform, 2019 8th Int. Conf. Agro-Geoinformatics, AgroGeoinformatics 2019. (2019) 1-6. doi:10.1109/Agro-Geoinformatics.2019.8820209.

[33] H.E. Beck, T.R. McVicar, A.I.J.M. van Dijk, J. Schellekens, R.A.M. de Jeu, L.A. Bruijnzeel, Global evaluation of four AVHRR-NDVI data sets: Intercomparison and assessment against Landsat imagery, Remote Sens. Environ. 115 (2011) 2547-2563. doi:10.1016/j.rse.2011.05.012.

[34] R.K. Nayak, N. Mishra, V.K. Dadhwal, N.R. Patel, M. Salim, K.H. Rao, C.B.S. Dutt, Assessing the consistency between AVHRR and MODIS NDVI datasets for estimating terrestrial net primary productivity over India, J. Earth Syst. Sci. 125 (2016) 11891204. doi:10.1007/s12040-016-0723-9.

[35] F.N. Kogan, Application of vegetation index and brightness temperature for drought detection, Adv. Sp. Res. 15 (1995) 91-100. doi:10.1016/0273-1177(95)00079-T.

[36] S.M. Quiring, S. Ganesh, Evaluating the utility of the Vegetation Condition Index (VCI) for monitoring meteorological drought in Texas, Agric. For. Meteorol. 150 (2010) 330-339. doi:10.1016/j.agrformet.2009.11.015.

[37] W.T. Liu, F.N. Kogan, Monitoring regional drought using the Vegetation Condition Index, Int. J. Remote Sens. 17 (1996) 2761-2782. doi:10.1080/01431169608949106.

[38] S.K. Jain, R. Keshri, A. Goswami, A. Sarkar, Application of meteorological and vegetation indices for evaluation of drought impact: A case study for Rajasthan, India, Nat. Hazards. 54 (2010) 643-656. doi:10.1007/s11069-009-9493-x. 
[39] O. Orhan, S. Ekercin, Konya Kapalı Havzasinda Uzaktan Algılama ve CBS Teknolojileri, in: TUFUAB VIII. Tek. Sempozyumu, Konya, 2015: pp. 202-208.

[40] M.A. Çelik, M. Karabulut, Farklı Bitki İndeks Modelleri (Evi, Ndvi, Vci) Kullanılarak Resulosman Dağı Kilis Bitki Örtüsünü İncelenmesi, in: Coğrafyacılar Derneği Uluslararası Kongresi, Coğrafyacılar Derneği, Muğla, 2014: pp. 372-379.

[41] R. Fensholt, I. Sandholt, Evaluation of MODIS and NOAA AVHRR vegetation indices with in situ measurements in a semi-arid environment, Int. J. Remote Sens. 26 (2005) 2561-2594. doi:10.1080/01431160500033724. 
